\title{
THE ROLE OF READING IN THE FORMATION OF A PERSON'S OPERATIVE MEMORY AND MENTAL MATURITY
}

\author{
Havasxon Omonovna Solieva
}

Teacher, Fergana Regional Branch Of Uzbekistan State Institute Of Arts And Culture, Uzbekistan

\section{ABSTRACT}

The growth of reading in our society is, first of all, a factor in the formation of a person's spiritual, mental maturity and operative memory. It is a systematic study of the importance of the reading factor, the importance of the reading factor and the ways and means of its optimization in ensuring a high socio-cultural environment of the country. Indeed, the book is a great force that lifts man from earth to heaven, increasing his spiritual power.

KEYWORDS:- Reading, reading culture, book, book products, reader, information-library, object-subjectobject, reading technology, reading level.

\section{INTRODUCTION}

Today, the state pays special attention to the development of reading in our society, especially the development of a culture of reading among young people, and a lot of effective work is being done. In particular, the Decree of the President of the Republic of Uzbekistan dated January 12, 2017 "On the establishment of the Commission for the development of the system of printing and distribution of books, the promotion of the culture of reading and reading", September 13, 2017 "Development of the system of publishing and distribution of books, on a comprehensive program of measures to increase and promote the culture of reading and readingImplementation of a number of organizational and practical measures aimed at developing the culture of reading in our country on the basis of the decisions of May 12, 2018 "On the organization of reading competitions among young people to widely study and promote the creative heritage of great scientists, writers and thinkers." laid the groundwork for a change in direction.

Uzbekistan has entered a new stage of development on the basis of the principle "From national revival to national progress." The intensity of the new era plays a special role in inculcating noble values and traditions in society, in particular, in raising the spiritual and intellectual potential, consciousness and worldview of our people, especially the younger generation, in raising a harmoniously developed personality is doing.

When the ability to read a book is formed in 
CURRENT RESEARCH JOURNAL OF PEDAGOGICS 2(11): 178-185,

November 2021 DOI: https://doi.org/10.37547/pedagogics-crjp-02-11-33

ISSN 2767-3278

(C)2021 Master Journals

Crossref do: 81 Google

Accepted 25th November, 2021 \& Published 30 ${ }^{\text {th }}$ November, 2021

young people, the book itself teaches all the actions that remain on the path to maturity. Therefore, it is reading that gives a person knowledge and information, enriches his spiritual world. The culture of reading teaches the reader to fully understand the source, to enjoy it spiritually and aesthetically, to understand and evaluate the author's thoughts and ideas.It also teaches how to use books and libraries, how to find resources on topics of interest or need, and how to use them in reading, work, and life. The culture of reading also includes choosing a book, reading it quickly, storing it carefully, setting up a personal library, and recommending the books you read to others. Hence, the culture of reading directs a person to directly engage in practice, to adapt to life, to gain spiritual benefits.

Although the word "mutolaa" actually means reading in Arabic, we think that today it means a broader concept than reading a book. The culture of reading is the knowledge, norms, social phenomena and other attributes that represent the system of changes in the content and components of the process, behavior and activities of social groups, associations and individuals aimed at obtaining general information.

Reading culture, in turn, requires an interest in books, an incentive for people to become more familiar with literature, specialized knowledge of the book and how to work with it, as well as skills and competencies that help to make full use of information sources.

At the same time, specialized information, which specifically shapes the culture of reading through educational systems, is used throughout human life through various sources - books (artistic, scientific, educational, encyclopedic, etc.), media (newspapers, magazines, television, radio, etc.), modern information technologies ( internet, enewspapers, magazines, manuals, etc.), as well as general information in various directions and forms obtained through persons who have direct contact with the subject (family members, work or study, neighbors and other people).Thus, an important component of the formation of a culture of reading is the principles of voluntariness, awareness in education, free choice of activities, conscious motivation for improvement, internal motivation, which are the driving forces for human development.

Based on the analysis of the sources on the definition of reading culture, we consider it expedient to group them in the following order:

- on the basis of emphasizing the priority of social goals observed in the culture of reading;

- Increased awareness of the need for humanitarian approaches in world development, based on the importance of understanding the priority of social needs;

Based on the view that spiritual suggestions are the basic principle of determining the direction of social development.The set of definitions given to the culture of reading in the existing scientific literature can be classified according to their general nature as follows. This concept:

1) expresses the combination of reading level, reading practice and reading opportunities (Farobi, G. Spencer, Locke);

2) emerges as an expression of the gradual changes in the phenomena of social consciousness, social practice and social perspective (E. Kant, Gegel, Russo);

3) each historical and cultural environment emerges as a constituent phenomenon under the influence of ethnoregional peculiarities (Alisher Navoi, Bobur, Furkat);

4) is interpreted as a socio-historical process that is naturally formed as a result of the gradual development of mankind from 
CURRENT RESEARCH JOURNAL OF PEDAGOGICS 2(11): 178-185,

November 2021 DOI: https://doi.org/10.37547/pedagogics-crjp-02-11-33

ISSN 2767-3278

(C)2021 Master Journals

Crossref doi) 81 Google

Accepted 25th November, 2021 \& Published 30 ${ }^{\text {th }}$ November, 2021

traditional society to industrial and postindustrial society (D. Bell, E. Toffler);

5) enlightenment is explained as a priority factor, and the perfection of each person ultimately ensures the perfection of society (A. Donish, Ya. Comenius, Behbudi, Fitrat);

6) in the development of mankind is seen as a natural-logical product of the gradual transition of products, goods, relations and exchange of information from direct to indirect states (A. Moturidi, M. Weber);

7) is interpreted as a logical product of the construction of the processes of general human development on the basis of the principle of supply and demand;

8) is interpreted as a specific manifestation of the extraordinary rise of human consciousness in an informed society;

9) the direction of the political system in society is considered as a socio-political phenomenon that is formed in connection with the systems of ideological influence;

10) a factor of human development - interpreted as a means of striving for innovation, bringing science, education, culture to unprecedented levels of perfection;

11) In some sources, the culture of reading is interpreted as a social process directly related to education.

In almost all studies of the culture of reading, this phenomenon is considered to be a "book-readerlibrary" system this process is explored in the "object-subject-object" direction. Reading culture is not studied in terms of reading technology, reading level, and reading intensity system. Or the characters that make up this system are interpreted separately, that is, without a certain harmony. This prevents the study of the phenomenon of reading culture from being directed to the end result. It is natural that the system "object - subject - object" can not be combined with the system "subject - subject object". In this traditional "object-subject-object" system, no attention is paid to the study in the form of "author-reader", "reader-librarian", "experienced reader-inexperienced reader", "book-reader" relations.

Researchers in the sociology and psychology of reading in developed Western countries have already abandoned the "object-subject-object" system. Reading technology, reading rate, and reading intensity are now being studied as important system-building features.

The quantitative aspect of reading technology, on the other hand, is reflected in the speed or slowness of the reader's reading. The importance of speed reading in the reading phenomenon is high. In the process of reading, a person's operative memory and attentional stability are formed. These two, in turn, ensure the mental maturity of the individual. The intellectual development of every member of society is the main goal of the concept of a perfect human being in our country and our efforts to form a comprehensively healthy generation.

It has been pointed out since the beginning of the last century that reading technology refers to the ways in which the reader assimilates a text, and that this process has both qualitative and quantitative aspects. According to N.A. Rubakin, the quality of the text assimilated by the reader is determined by the degree to which he understands the content of the text and the extent to which he can apply the understood concepts to life.

The second system-forming feature of reading culture is that the level of reading is also related to reading technology, which indicates the level of information comprehension by the reader. There are, in our view, four stages of this. They are: 
CURRENT RESEARCH JOURNAL OF PEDAGOGICS 2(11): 178-185,

November 2021 DOI: https://doi.org/10.37547/pedagogics-crjp-02-11-33

ISSN 2767-3278

(C)2021 Master Journals

Crossref doi) 81 Google

Accepted 25th November, 2021 \& Published 30 ${ }^{\text {th }}$ November, 2021

In the first level, the reader understands the content of the text and remembers the plot of the story being narrated and its main aspects.

At the second level, the reader demonstrates the ability to understand the content of the text as well as the plot and to predict the course of events to a certain extent.

At the third level, the reader is able to evaluate the behavior of the protagonists and analyze the episodes of the work, expressing their independent attitude to the text and the event narrated in it.

At the fourth level, the reader is able to fully understand the content of the text and analyze the event independently. By analyzing the behavior of the protagonists on the basis of the logic of events, one can draw synthetic, i.e. generalized, conclusions.

It is necessary to form these levels of reading in our citizens from an early age. One of the main goals of composing a perfect person is to bring each person to the fourth level of the above sequence. This in turn means that high reading efficiency is ensured.

The most important system-forming feature of reading culture is the intensity of reading, which is understood as the rate of periodic use of reading resources. That is, how many newspapers and magazines a person reads in a week, or how many books a person reads in a year, determines the reading intensity of that person. The intensity of reading is proportional to the level of reading culture in the society, and the higher the intensity, the higher the reading culture.

The factors that ensure a high reading intensity are:

1. High level of interest in reading and information. This trait begins to take shape in a person from a young age, from a school desk, even from kindergarten. So, one of the important aspects of the development of harmoniously developed individuals in society is the formation of interest in reading among students.

2. Reading sources are interesting and rich in content. To ensure this, it is necessary to increase the content of reading sources, as well as to publish more examples of masterpieces of world and national classics, modern works created with high talent and skill.

3. Provide easy access to reading resources. There are two factors to this, the first being the economic factor. That is, the price of reading resources should be commensurate with the purchasing power of the population.It is necessary to protect the reading needs of socially vulnerable groups,to provide free books and subscriptions to newspapers and magazines to the poor and disabled. Another aspect is the convenient location of the facilities where the reading sources are distributed. That is, libraries, Internet cafes, book and newspaper shops should be located on the basis of a long-term plan, taking into account the interests of readers and journalists.

4. Advertising of various literature and other reading sources should be expanded in accordance with the requirements of a market economy.

Sociological research in a number of Western countries, as well as in Russia, shows that the demand for pre-advertised publications is always high, with a clear goal in mind. Publishers in developed countries have been using this factor skillfully. Because, on the one hand, this is done for economic gain, on the other hand, it contributes to the growth of the intensity of reading in society, and, consequently, to the development of a culture of reading. 
CURRENT RESEARCH JOURNAL OF PEDAGOGICS 2(11): 178-185,

November 2021 DOI: https://doi.org/10.37547/pedagogics-crjp-02-11-33

ISSN 2767-3278

(C)2021 Master Journals

Crossref do: 81 Google

Accepted 25th November, 2021 \& Published 30 ${ }^{\text {th }}$ November, 2021

The three factors mentioned above - the technology of reading, the level of reading and the successful application of reading intensity in practice - are the necessary foundations for the growth of reading culture.

Undoubtedly, the most important institutions in the formation of a culture of reading in society are information and resource centers (IRCs), information and library centers, ILCs and libraries. "... the library is a window into the world of knowledge for the local population and one of the important foundations of lifelong learning, independent decision-making and cultural development of individuals and social groups." Libraries are also important because they have a large collection of reading resources, convenient and modern conditions for access to information, services by staff with higher or specialized knowledge, as well as professional staff in the process of forming a culture of reading in society. At the same time, IRCs, ILCs and libraries, which are the main social institutions that serve to raise the general knowledge of the population, contribute to the education of the perfect person.

According to the researchers, the following aspects of IRC, ILC and libraries can make them one of the main educational institutions that form a perfect person in society:

1) the possession of libraries by collections of literature rich in emotional, moral and spiritual potential;

2) implementation of educational processes in libraries, which are cultural and educational institutions, in mass, group and individual forms;

3) libraries have knowledgeable, spiritually and morally pure servants who are in constant contact with the book;

4) libraries unite the active layer of intellectuals;
5) libraries have become the cheapest way for the population to get acquainted with cultural values;

6) interaction of libraries as a socio-spiritual institution in interaction with other institutions of social influence of society.

Today, the formation of a culture of reading in Uzbekistan aims to achieve the following goals:

- Contribute to the high quality of reading culture and the deep economic and social reforms underway in the country, the training of competitive personnel that meet the requirements of building a developed democratic state;

- regulation of the content of reading based on the prospects of social and economic development of the country, the needs of society, modern achievements of science, engineering and technology;

- democratization, humanization and socialization of education, increasing the level of legal and economic knowledge of students, as well as the effectiveness of the reading process;

- protection of the interests of the individual, society and the state in the provision of quality library services, education and training;

ensuring the consistency and continuity of the educational process and training, the place of reading in this system, and so on. Indeed, the book is a great force that lifts man from earth to heaven, increasing his spiritual power. It is a torch that strengthens the historical memory of mankind, the spiritual and enlightenment world, the scientific basis, and the bright future.

\section{ReFERENCES}

1. Resolution of the President of the Republic of Uzbekistan dated September 13, 2017 No PP- 
CURRENT RESEARCH JOURNAL OF PEDAGOGICS 2(11): 178-185,

November 2021 DOI: https://doi.org/10.37547/pedagogics-crjp-02-11-33

ISSN 2767-3278

(C)2021 Master Journals

Crossref do: 81 Google

Accepted 25th November, 2021 \& Published 30 ${ }^{\text {th }}$ November, 2021

3271 "On a comprehensive program of measures to develop the system of publishing and distribution of book products, increase and promote the culture of reading and reading"

2. Karimov I. A. High spirituality is an invincible force. - Tashkent: Manaviyat, 2008.

3. Mirziyoev Sh. The consent of our people is the highest value given to our activities. Volume 2, T: “Uzbekistan”, 2018.-508p.

4. Rubakin N.A. Letter to readers about selfeducation. - V izb. proizv. T.2. M .: Kniga, 1975. - p. 52.

5. Yuldashev E. Supervise children's reading in the library. Study guide. - T .: Uzbekistan, 2002;

6. Maxmudov M.X. Providing library services to teachers in the school library. T .: 1992; Islomov E.G., Yuldashev I.Yu. Rabota shkolnoy biblioteki.- T .: 1989 7.Ziyoev S.A., Roziqova Yo.M. The role of the school library in the spiritual education of youth // 60th anniversary of the Republican Scientific Pedagogical Library (1934-1994): Theses of the scientific-practical conference.- T .: 1994.B. 33-34.

7. Boltaboeva, U., Abdunazarov, Z., \& Usmonov, S. (2021). The balance of language and speech in the Uzbek theater. ASIAN JOURNAL OF MULTIDIMENSIONAL RESEARCH, 10(4), 788-792.

8. Абдуназаров, 3. (2021). ИЖОДИЙ СИНТЕЗ ЖАРАЁНЛАРИНИ ТАШКИЛ ЭТИШДА РЕЖИССЁРНИНГ РОЛИ. Oriental Art and Culture, (6).

9. Haydarov, A., Akbarov, T., \& Abdunazarov, Z. (2020). High purpose and leading action. ACADEMICIA: AN INTERNATIONAL MULTIDISCIPLINARY RESEARCH JOURNAL, $10(12), 609-615$.
10. Akbarova, M., Tursunova, G., \& Abdunazarov, Z. (2020). Pedagogical aproaches to the formation of musical literacy of students in the sytem of Higher Education. European Journal of Arts, (1), 125-128.

11. Абдуназаров, 3. (2020). Тимсоллар сиймосини яратиш. Oriental Art and Culture, (III), 146-150.

12. Абдуназаров, 3. (2020). Миллий уйинларимиз иштирокида ёш актёрларни тасаввури ва диққатини чархлаш. Oriental Art and Culture, (III), 134-138.

13. Akbarova, M., Tursunova, G., \& Abdunazarov, Z. (2020). Pedagogical aproaches to the formation of musical literacy of students in the sytem of Higher Education. European Journal of Arts, (1), 125-128.

14. Болтабоева, У. (2020). ҚЎҒИРЧОҚ ТЕАТРИ ГУРУХЛАРИДА САХНАВИЙ НУТҚНИНГ АХАМИЯТИ. Oriental Art and Culture, 1(5), 85-92.

15. Boltaboeva, U., Gofurova, B., Pulatov, R., \& Mamatkulov, B. (2020). Methods of improving the young actors speech. ACADEMICIA: AN INTERNATIONAL MULTIDISCIPLINARY RESEARCH JOURNAL, 10(12), 1114-1123.

16. Болтабоева, У. (2021). МУСИҚАЛИ ДРАМА ТЕАТРЛАРИНИНГ РИВОЖЛАНИШИДА ТАРИХИЙ АСАРЛАРНИНГ РОЛИ. Oriental Art and Culture, (6).

17. Эргашев, К., \& Болтабоева, У. (2021). УЧИНЧИ РЕНЕССАНС ЁШЛАР НИГОХИДА. Oriental Art and Culture, (6).

18. Болтабоева, У. (2021). ЎЗБЕК ТЕАТРИ САХНАЛАРИДА ТИЛ ВА НУТҚ МУТАНОСИБЛИГИ. Oriental Art and Culture, (7), 171-180.

19. Boltaboeva, U., Abdunazarov, Z., \& Usmonov, S. (2021). The balance of language and 
CURRENT RESEARCH JOURNAL OF PEDAGOGICS 2(11): 178-185,

November 2021 DOI: https://doi.org/10.37547/pedagogics-crjp-02-11-33

ISSN 2767-3278

(C)2021 Master Journals

Crossref do: 81 Google

Accepted 25 $5^{\text {th }}$ November, 2021 \& Published $30^{\text {th }}$ November, 2021

speech in the Uzbek theater. ASIAN JOURNAL OF MULTIDIMENSIONAL RESEARCH, 10(4), 788-792.

20. Usmonov, S., Boltaboeva, U., \& Akbarov, T. (2021). Principles of working on a monologue with future actors. Asian Journal Of Multidimensional Research, 10(6), 28-38.

21. Boltaboeva, U., Usmonov, S., \& Akbarov, T. (2021). A Look at Askia Art. Annals of the Romanian Society for Cell Biology, 25(6), 2277-2284.

22. Usmonov, S., Boltaboeva, U., Rahmonova, N., \& Akbarov, T. (2021). Pedagogical Approaches To Educating Future Actors. The American Journal of Interdisciplinary Innovations Research, 3(05), 85-90.

23. Болтабоева, У. (2019). Ижодкор шахсактёрни тарбиялашда жонли сўзнинг ўрни. Oriental Art and Culture, (IV (1)), 3739.

24. Рахматуллаева, Ш., Болтабоева, У., \& Каримов, Б. (2019). Фольклор санъати ва халқ достонлари: кеча ва бугун. Oriental Art and Culture, (IV (1)), 46-49.

25. Boltaboeva, U., Andunazarov, Z., \& Tursunova, G. (2020). Importance of tongue twisters and proverbs in overcoming speech defects. Journal of Advanced Research in Dynamical and Control Systems, 12(2), 29022905.

26. Boltaboeva, U. (2019). Using Oral Folk Art Methods in Improving Speech Technology. Eastern European Scientific Journal, (1).

27. Boltaboeva, U., Sh, U., \& Rahmonova, N. (2019). Creative person-the role of live word in educating an actor. European Journal of Arts, (3).

28. Boltaboyeva, U., Rakhmonova, N., \& Usmonov, S. (2020). Characteristics of speech Art: problems and solutions. ACADEMICIA:
An International Multidisciplinary Research Journal, 10(4), 559-567.

29. Tursunova, G., \& Karimov, B. (2020). Factors that should be considered in musical theater actors education. ACADEMICIA: An International Multidisciplinary Research Journal, 10(11), 57-61.

30. Tursunova, G. (2021). BALET RAQS SAN'ATINING O'RNI VA TARIXIY TARAQQIYOTI. Oriental Art and Culture, (6).

31. Tursunova, G., \& Karimov, B. (2020). PEARLS OF UZBEK NATIONAL DANCE. International Engineering Journal For Research \& Development, 5(Conference), 4-4.

32. Yunusov, G. X., Juraev, I., \& Ahmedov, R. The European Journal of Arts, Issue 1/2020.

33. Yunusov, G., Ahmedov, R., Jurayev, I., \& Yuldasheva, S. (2021). A Look At The Folklore of Fergana Valley or History of A Song in The Series of Tanovar. Annals of the Romanian Society for Cell Biology, 25(6), 2225-2232.

34. Yunusov, G., Juraev, I., \& Ahmedov, R. (2020). A LOOK AT THE REGIONAL SEASONAL FOLKLORE AND THEIR ORIGIN. THE ROLE AND IMPORTANCE OF FOLKLORE IN THE DEVELOPMENT OF DANCE ART. European Journal of Arts, (1), 121-124.

35. Sohibaxon, Y. (2021). O'ZBEKISTONDA KUTUBXONACHILIK SOHASINING RIVOJI. Oriental Art and Culture, (7), 260-268.

36. Yunusov, G., Ahmedov, R., Jurayev, I., \& Yuldasheva, S. (2021). A Look At The Folklore of Fergana Valley or History of A Song in The Series of Tanovar. Annals of the Romanian Society for Cell Biology, 25(6), 2225-2232.

37. Yuldasheva, S., Habibjonov, I., \& Haydarov, A. (2020). Librarianship in the formation of book reading. Journal of Advanced Research in Dynamical and Control Systems, 12(2), 2925-2927. 
CURRENT RESEARCH JOURNAL OF PEDAGOGICS 2(11): 178-185,

November 2021 DOI: https://doi.org/10.37547/pedagogics-crjp-02-11-33

ISSN 2767-3278

(C)2021 Master Journals

Crossref do: 81 Google

Accepted 25th November, 2021 \& Published 30 ${ }^{\text {th }}$ November, 2021

38. Юлдашева, С. (2019). Китоб мутолаасини шакиллантиришда кутубхоначилик фаолияти. Oriental Art and Culture, (IV (1)), 59-62.

39. Yunusov, G., Ahmedov, R., Jurayev, I., \& Yuldasheva, S. (2021). A Look At The Folklore of Fergana Valley or History of A Song in The Series of Tanovar. Annals of the Romanian Society for Cell Biology, 25(6), 2225-2232.

40. Yuldasheva, S., \& Madumarova, M. (2020). TASKS AND CONTENT OF BIBLIOGRAPHIC WORKS. European Journal of Arts, (1), 148152.

41. Yunusov, G. X., Juraev, I., \& Ahmedov, R. The European Journal of Arts, Issue 1/2020.

42. GofirjonYunusov, R. A., Jurayev, I., \& Yuldasheva, S. (2021). A Look at the Folklore of Fergana Valleyor History of a Song in the Series of Tanovar. Annals of the Romanian Society for Cell Biology, 25(6), 2822-2827.

43. Yunusov, G., Juraev, I., \& Ahmedov, R. (2020). A LOOK AT THE REGIONAL SEASONAL FOLKLORE AND THEIR ORIGIN. THE ROLE AND IMPORTANCE OF FOLKLORE IN THE DEVELOPMENT OF DANCE ART. European Journal of Arts, (1), 121-124.

44. Talaboyev, A., Yunusov, G., \& Ahmedov, R. (2020). Local methods of traditional singing. Journal of Advanced Research in Dynamical and Control Systems, 12(2), 2916-2920.

45. Yunusov, G., Ahmedov, R., Jurayev, I., \& Yuldasheva, S. (2021). A Look At The Folklore of Fergana Valley or History of A Song in The Series of Tanovar. Annals of the Romanian Society for Cell Biology, 25(6), 2225-2232.

46. Yunusov, G., Juraev, I., \& Ahmedov, R. (2020). A LOOK AT THE REGIONAL SEASONAL FOLKLORE AND THEIR ORIGIN. THE ROLE AND IMPORTANCE OF FOLKLORE IN THE DEVELOPMENT OF DANCE ART. European
Journal of Arts, (1), 121-124.

47. Usmonov, S., \& Talaboyev, A. (2021). Work of the director with an artist. ACADEMICIA: An International Multidisciplinary Research Journal, 11(3), 2407-2410.

48. Талабоев, А. (2019). Мақом санъатида сўзнинг ўрни. Oriental Art and Culture, (IV (1)), 25-28.

49. Talaboev, A., Akbarov, T., \& Haydarov, A. (2020). SONG PERFORMING IN TRADITIONAL PERFORMING ARTS: PAST AND PRESENT TIM. European Journal of Arts, (1), 85-88.

50. Dadaboev, Y., \& Dehqonov, R. Hordo Structures in Central Asian Architecture.

51. Utaganov, R., Dehqonov, R., \& Tuxtasinov, M. (2020). MAIN ADVANTAGES OF TEACHING METHODS IN ARTS. European Journal of Arts, (2), 146-148. 